\title{
Work characteristics and occupational health: validation and proposal of a shortened version of the Work Design Questionnaire
}

\author{
Antonio L. García-Izquierdo, and Ana M. Castaño*
}

\section{Universidad de Oviedo}

Título: Características del trabajo y salud ocupacional: validación y propuesta de una versión abreviada del Work Design Questionnaire.

Resumen: El interés por el estudio de las características del trabajo para explicar cómo la relación de un individuo con el entorno laboral puede conducir a respuestas desadaptativas ha cobrado una importancia renovada a la luz de la creciente preocupación por el desarrollo de organizaciones saludables y por la diversidad organizacional. Este estudio tiene como objetivo desarrollar una versión abreviada del Work Design Questionnaire (WDQ) con el fin de facilitar su uso e interpretación en este contexto. Las propiedades psicométricas de este cuestionario reducido se probaron en una muestra multisectorial de trabajadores en España. Para ello, aplicamos el cuestionario a una muestra de 500 trabajadores y analizamos la relación entre las carácterísiticas del trabajo y las variables seleccionadas de salud ocupacional (satisfacción, bienestar y agotamiento emocional). Los resultados mostraron una fiabilidad y una validez orientada al criterio adecuadas para la versión abreviada del WDQ, esto es, el WDQ18-S, así como evidencia de invarianza factorial de género. Posteriormente se discuten los resultados y sus implicaciones para el uso del WDQ en el ámbito aplicado e investigador de la salud ocupacional y la prevención de riesgos laborales.

Palabras clave: Características del trabajo. Work Design Questionnaire. Invarianza de género. Salud ocupacional. Versión abreviada. Validación.
Title: Work characteristics and occupational health: validation and proposal of a shortened version of the Work Design Questionnaire

Abstract: Interest in the study of work characteristics to explain how an individual's relationship with the work environment can lead to maladaptive responses has taken on renewed importance in the light of increasing concern for the development of healthy organizations and organizational diversity. This study aims to develop a shortened version of the Work Design Questionnaire (WDQ) with a view to facilitating its use and interpretation. The psychometric properties of this shorter questionnaire were tested in a multi-sectoral sample of workers in Spain, with due consideration given to the gender measurement invariance. For this purpose, we applied the questionnaire to a sample of 500 workers and analyzed the relationship between the answers provided to WDQ and specific occupational health variables (satisfaction, well-being and emotional exhaustion). Results showed adequate reliability and criterion-oriented validity for the shortened version of the WDQ, that is, the WDQ18-S, as well as evidence of factorial invariance across gender. We then discuss the results and their implications for the application of the WDQ in further research and the field of occupational health and psychosocial risks prevention.

Keywords: Work characteristics. Work Design Questionnaire. Gender invariance. Occupational health. Shortened version. Validation.

\section{Introduction}

The way in which work characteristics in organizations impact on occupational health has been the subject of considerable research (e.g., Parker et al, 2017). This is hardly surprising when one considers that these characteristics can contribute to an increased probability of harm to workers, play a role in the onset of occupational diseases, exacerbate existing occupational diseases, and represent the root cause of occupational accidents (e.g., López-Araújo \& Osca, 2010). However, the way in which work characteristics are perceived also plays a decisive role. Their analysis requires the consideration of a worker's subjective perception of the work environment (Parker, 2014) in order to understand and explain how an individual's particular and unique relationship with the work environment can lead to maladaptive responses, errors, accidents and adverse outcomes for organizations. The importance of such working characteristics led Morgeson and Humphrey (2006) to develop the Work Design Questionnaire (WDQ). This instrument has been validated in different contexts and languages, including Germany (Stegmann et al., 2010), Brazil (Borges-Andrade et al., 2019), France (Bertolino et al., 2011) and the Netherlands (Gorgievski-Duijvesteijn et al., 2016). To the best of our knowledge, there are two Spanish

* Correspondence address [Dirección para correspondencia]: Ana Castaño. Universidad de Oviedo. Facultad de Psicología, Plaza Feijoo s/n, 33003, Despacho 306, Oviedo (Spain). E-mail: castanoana@uniovi.es (Article received: 18-5-2021, revised: 6-7-2021, accepted: 2-8-2021) versions of the WDQ to date, the version developed by Bayona et al. (2015) and the version developed by Fernández et al. (2017). The former translated and validated the WDQ in a sample of 831 Colombian workers, while the latter validated the WDQ in a sample of 1035 workers in Spain. However, further research is required to analyze whether the WDQ can be applied in the Spanish context while maintaining adequate psychometric properties and demonstrating measurement invariance, given that the work contexts in Colombia and Spain are qualitatively different, both in the composition and distribution of qualifications and the economic sectors involved. Furthermore, given the type of target population (i.e., workers with different qualifications), the length of the questionnaire ( 77 items) and the time required for its completion can easily lead to problems with the rate and quality of responses, for example, issues concerning common method variance, that can have a significant impact on the relationships between measures of different constructs (Podsakoff et al. 2003). Participants might feel fatigue toward the end of the survey's questions which results in providing consistent answers regardless of what the questions are about (Baumgartner \& Steenkamp, 2001; Krosnick, 1999; MacKenzie \& Podsakoff, 2012). In addition, ever-increasing information saturation in the workplace means that the time available for completing online questionnaires is becoming increasingly scarce. The work context is currently undergoing drastic changes due to the extensive use of information technologies and social networks (Aguado et al, 2019). Constantly accelerating 
interaction has made work more intense, with hyper connectivity and an assumption of constant availability exerting a certain pressure for immediate response in communication (García-Izquierdo et al., 2019). Consequently, conducting lengthy questionnaires against such a background can have an adverse effect on the quality and quantity of the responses provided. Developing a shorter instrument that is easier to apply and quicker to answer will contribute to improving the construct validity of the questionnaire, and therefore the adequacy of the data obtained for subsequent analysis and interpretation. In this respect, it would seem advisable to shorten the WDQ so as to facilitate its future application (e.g., Liu \& Wronski, 2018; Marcus et al., 2007), particularly when applying the questionnaire to workers with lower qualifications and/or levels of training.

Moreover, we have seen renewed and intensified interest in the study of work characteristics in response to the published objectives of the Decent Work Agenda (International Labor Organization, 2020) and the Sustainable Development Goals of the United Nations, which place special emphasis on the development of healthy organizations and organizational diversity (Castaño et al., 2019). It is precisely this commitment to diversity that makes it necessary to analyze the WDQ short form measuring gender invariance, as studies involving the WDQ in Spain have not taken into account differences in vulnerability and exposure to risk factors for women and men, so research on the promotion of occupational safety and health have largely failed to take sufficient account of specific differences in the individual circumstances of women and men when designing workplaces (e.g., Gartzia et al., 2018).

Taking all of the above into consideration, the aim of this study is to analyze the psychometric properties of the WDQ in a multi-sectoral sample of workers in Spain, and to test whether a shortened version of this questionnaire retains these properties. A shorter version of the WDQ would provide a more flexible measurement instrument that is easier to understand, faster to apply and of greater use for research and professional purposes. In addition, we include an invariance analysis that takes into account the gender of the respondents. Firstly, we present an analysis of the components of the WDQ. Secondly, we conduct a study of the properties of the WDQ that includes reduction and invariance analysis. Thirdly, we present an analysis of the work characteristics measured by the shortened version of the WDQ and their relationship with organizational health variables, with due consideration given to the impact of gender. And finally, we discuss the results and implications for the application of the WDQ in further research and the field of occupational health.

\section{Work characteristics and occupational health: the WDQ}

Work characteristics are relevant to occupational health to the extent that they can represent risk factors, which is to say, any aspect of the work environment where exposure significantly increases the probability of an individual suffering an adverse health outcome. This may take the form of a disorder, syndrome, disease or injury, and will also impact on the performance of the worker and the organization. When these risk factors derive from the way in which work is organized and the relationships that exist within an organization, we are referring to psychosocial risk factors (e.g., Cox \& Griffiths, 1996; Leka \& Cox, 2008). These risk factors are counterbalanced by protective factors that reduce the probability of the occurrence of the dysfunctional or pathological response. Depending on the case, whether a factor is a risk factor or a protective factor will depend on various aspects, such as intensity, frequency or the type of relationship between the variables, whether linear or non-linear.

Morgeson and Humphrey (2006) tried to measure work characteristics and conducted a study in the USA with 540 incumbents holding 243 distinct work positions and developed the WDQ, composed of three categories of work characteristics. The first category (i) refers to motivational characteristics, which include the factors task and knowledge characteristics, given that job enrichment is improved when high levels of these characteristics are present. Task characteristics refers to the work involved in any given work position and the way in which the required tasks are carried out, and include the following variables: work scheduling autonomy, decision-making autonomy, work methods autonomy, task variety, task significance, task identity and feedback from job. The WDQ also includes knowledge characteristics, which refer to the knowledge, skill and ability demands on the job, and include the following variables: job complexity, information processing, problem solving, skill variety and specialization. (ii) The second category is composed of social characteristics, which refer to relationships with others, and include: social support, initiated interdependence, received interdependence, interaction outside the organization, and feedback from others. Finally, (iii) the third category is composed of work context characteristics, which refer to the physical environment of the workplace, and include the variables: ergonomics, physical demands, work conditions and equipment use.

Empirical analysis of the constructed questionnaire showed that the 21-factor version was the WDQ that presented the best psychometric properties after analyzing the following five factorial structures: (i) 4 factors, where items are grouped into the four general categories of task, knowledge, social and work context characteristics; (ii) 18 factors, where autonomy and interdependence are each considered as a single factor rather than separated into work 
scheduling, decision-making and work methods autonomy, and into initiated and received interdependence; (iii) 19 factors, where autonomy is considered a single factor rather than separated into three factors, as in the previous case, and interdependence is divided into initiated and received interdependence; (iv) 20 factors, where autonomy is divided into work scheduling, decision-making and work methods autonomy, and interdependence is considered a single factor; and (v) 21 factors, where autonomy and interdependence are divided into their respective components, as described above. Bayona et al. (2015) and Fernández et al. (2017) obtained similar results with their corresponding Spanish versions of the WDQ, with the 21-factor structure obtaining the best results. However, more recent research by Borges-
Andrade et al. (2019) on Brazilian workers, and by Peiró et al. (2020) on Colombian workers, found that the 18-factor structure was the most suitable version. Given that a shorter version of the questionnaire would facilitate its application, we will therefore study the possibility of reducing the length of the WDQ while maintaining its adequate psychometric properties (Objective 1).

With respect to criterion-oriented validation of the WDQ (Table 1) we have found several studies (e.g., Bargsted et al., 2019; Bayona et al., 2015; Gorgievski-Duijvesteijn et al., 2016; Humphrey et al., 2007; Morgeson \& Humphrey, 2006; Stegmann et al., 2010) where we can see evidences between the WDQ and occupational health variables, specifically job satisfaction, burnout, and well-being.

Table 1

Found and expected relations between the dimensions of the $W D Q$ and occupational health outcomes for bypotheses $H_{1}-H_{3}$.

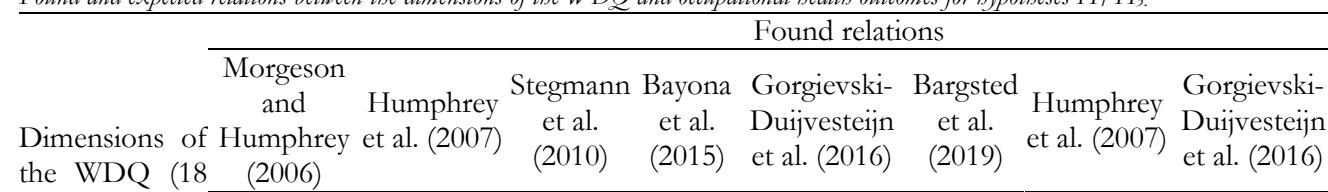
factors)

Job satisfaction

\begin{tabular}{|c|c|c|c|}
\hline $\begin{array}{l}\text { Stress } \\
\text { (i.e., burnout, stress, } \\
\text { job strain) }\end{array}$ & $\begin{array}{c}\text { Job } \\
\text { satisfaction } \\
\left(\mathrm{H}_{1}\right)\end{array}$ & $\begin{array}{c}\text { Burnout } \\
\text { (emotional } \\
\text { exhaustion) } \\
\left(\mathrm{H}_{2}\right)\end{array}$ & $\begin{array}{c}\text { Well } \\
\text { bein } \\
\left(\mathrm{H}_{3}\right)\end{array}$ \\
\hline
\end{tabular}

\begin{tabular}{|c|c|c|c|c|c|c|c|c|c|c|c|c|}
\hline Autonomy & + & + & + & + & + & + & - & - & n.s. & $+* \#$ & $\begin{array}{c}\left(\mathrm{H}_{2}\right) \\
-* \#\end{array}$ & $+* \#$ \\
\hline Task variety & + & + & + & + & + & + & & & + & $+*$ & n.s. \# & - \\
\hline $\begin{array}{l}\text { Task } \\
\text { significance }\end{array}$ & + & + & + & + & + & + & - & n.s. & n.s. & $+* \#$ & -*\# & n.s. \\
\hline Task identity & + & + & + & + & + & + & - & - & - & $+* \#$ & $-*$ & $+* \#$ \\
\hline $\begin{array}{l}\text { Feedback from } \\
\text { job }\end{array}$ & + & + & + & + & + & + & n.s. & - & n.s. & $+* \#$ & n.s. & $+* \#$ \\
\hline Job complexity & + & + & + & n.s. & + & & & & + & + & n.s. & - \\
\hline $\begin{array}{l}\text { Information } \\
\text { processing }\end{array}$ & + & + & + & + & + & & & & + & + & n.s. ${ }^{* \#}$ & - \\
\hline $\begin{array}{l}\text { Problem } \\
\text { solving }\end{array}$ & + & & + & + & + & & & & + & $+*$ & n.s. ${ }^{* \#}$ & - \\
\hline Skill variety & + & + & + & + & + & . & n.s. & n.s. & + & $+*$ & n.s.*\# & - \\
\hline Specialization & + & ㄱ․ & + & + & + & & & & + & $+* \#$ & n.s.*\# & - \\
\hline Social support & + & + & + & + & + & + & - & - & - & $+* \#$ & $-* \#$ & $+* \#$ \\
\hline $\begin{array}{l}\text { Initiated and } \\
\text { received inter. }\end{array}$ & n.s. & + & n.s. & n.s. & n.s. & + & & - & + & n.s.*\# & n.s. ${ }^{\#}$ & - \\
\hline $\begin{array}{l}\text { Interaction } \\
\text { outside } \\
\text { organization }\end{array}$ & + & + & n.s. & n.s. & n.s. & + & & & n.s. & + & n.s. ${ }^{* \#}$ & n.s. ${ }^{* \#}$ \\
\hline $\begin{array}{l}\text { Feedback from } \\
\text { others }\end{array}$ & n.s. & + & + & + & + & + & - & - & n.s. & $+* \#$ & -* & + \\
\hline Ergonomics & + & & + & + & + & & & & n.s. & $+* \#$ & n.s. & n.s. \\
\hline $\begin{array}{l}\text { Physical } \\
\text { demands }\end{array}$ & n.s. & - & - & - & + & & & & - & $+* \#$ & n.s. & $+*$ \\
\hline $\begin{array}{l}\text { Work } \\
\text { conditions }\end{array}$ & + & + & + & + & + & & n.s. & - & n.s. & $+* \#$ & n.s. & $+*$ \\
\hline Equipment use & n.s. & & n.s. & n.s. & n.s. & & & & n.s. & n.s. ${ }^{* \#}$ & n.s.*\# & n.s.*\# \\
\hline
\end{tabular}

Note. + A significant and positive relationship. - A significant and negative relationship. n.s. Non significant correlation. Left blank when no data are available. * Supported hypotheses. \# Supported hypotheses taking the $r \geq .144$ threshold.

Taking all of the above into consideration, we expect to find the following relationships in this study with the short form of the WDQ, expressed in hypotheses H1-H3, and summarized in Table 1: 
$H_{1}$. Autonomy, task variety, task significance, task identity, feedback from job, job complexity, information processing, problem solving, skill variety, specialization, social support, interaction outside the organization, feedback from others, ergonomics, physical demands and work conditions will be positively and significantly correlated with job satisfaction.

$H_{2}$. Autonomy, task significance, task identity, social support and feedback from others will be negatively and significantly correlated with burnout (emotional exhaustion).

$H_{3 .}$ Autonomy, task identity, feedback from the job, social support, feedback from others, physical demands and work conditions will be positively and significantly correlated with well-being, while task variety, job complexity, information processing, problem solving, skill variety, specialization, and initiated and received interdependence will be negatively and significantly correlated with well-being.

\section{Gender and work conditions}

It is vitally important to take gender into account when analyzing working conditions, as the failure to do so risks overlooking any differences that may exist in vulnerability and exposure for women and men. These differences derive from the implementation of occupational safety and health standards that are primarily geared towards men, and a failure to take into account that, due to gender roles, women and men may not perform the same tasks (e.g., Osca \& López-Araújo, 2020), or perform tasks in the same way. Gender division of work can be explained by gender roles theories, as the Role Congruity Theory of Prejudice Toward Female Leaders (Eagly \& Karau, 2002), and the Status Incongruity Hypothesis (Rudman et al., 2012). These theories posit that women have been historically consigned to feminized positions (e.g., Castaño et al., 2019). Feminized work would appear to be more related to employment in positions with less responsibility, more repetitive tasks, and a heavier family burden; while masculinized work is related to positions of greater responsibility that require more overtime and greater overload (e.g., Cifre et al., 2015). In this regard, the study by Rivera-Torres et al. (2013) on work stress showed that men are more often affected than women by quantitative demands, such as having to work rapidly and under greater time pressure; while women are more often affected by qualitative, intellectual, emotional and social support demands. At the same time, different risks may be present when women and men occupy positions that are stereotypically considered inappropriate for their gender (e.g., García-Izquierdo et al., 2018).

In short, this all points to the fact that women and men may suffer different consequences for their health and wellbeing. Indeed, these differences have been corroborated in several meta-analyses (e.g., Batz-Barbarich et al., 2018; Purvanova \& Muros, 2010) in which women's emotional exhaustion and job dissatisfaction scores were also found to be higher than those of men.
Taking all the above into consideration, in this study we expect to find that:

$H_{4}$. Women will score lower than men on job satisfaction and wellbeing, while scoring higher on emotional exhaustion.

We will also analyze the invariance of the shorter version of the WDQ in order to ensure that it provides equivalent measurement irrespective of gender (Objective 2). This will contribute to the consideration of the gender perspective in occupational health future research. In addition, we will explore gender differences with respect to the work characteristics analyzed in the shorter version of the WDQ (Objective 3).

\section{Method}

\section{Procedure}

A protocol was developed prior to commencing the research that was subsequently assessed by an independent ethics review committee ${ }^{1}$. Having approved the protocol, the researchers conducting the study trained several interviewers. Trained interviewers asked diverse companies and workers for participation. Participation criteria were: to be working at least six months during the last two years in Spain, and not to be self-employed nor to be a student. We requested the collaboration to fill an online questionnaire of a number of incumbents and then to distribute that link to other workers selected by means of non-probabilistic snowball sampling. The questionnaire included socio-demographic variables and various scales. All participants acknowledged informed consent before completing the questionnaire.

Respondent anonymity and the research purpose were emphasized throughout the process in order to avoid social desirability effects and reduce evaluation apprehension (e.g., Podsakoff et al., 2012).

\section{Participants}

A total of 566 people participated in the study. However, 66 responses were discarded for the following reasons: (i) 39 self-employed respondents completed the questionnaire, despite the fact that the questionnaire is intended for salaried employees; (ii) four participants were discarded because they indicated that they had no work experience beyond their final student work placement; and (iii), the contributions of 23 participants were discarded because they failed to correctly follow the instructions for answering two items (e.g., "Please indicate option $[\mathrm{X}]$ for this question"), which were included to avoid low-quality data (DeSimone \& Harms, 2017).

The final sample of 500 participants consisted of 234 men $(46.8 \%)$ and 266 women $(53.2 \%)$, with a mean age of

1 Comité de Ética en la Investigación del Principado de Asturias (Ethics Committee on Research of the Principality of Asturias, reference project: 2020.119). 
37.59 years $(S D=12.704)$. Of these, $61.2 \%$ had received a university education. In terms of work context, the average number of employees in the organizations to which the participants belonged was $252.19(S D=967.437)$, with $50 \%$ of the participants belonging to organizations with 30 or fewer employees, and around 10\% to organizations with 300 or more employees. $75 \%$ of the participants were from the private sector, and the remaining $25 \%$ from the public sector. Furthermore, as can be observed in Table 2, the incumbents were drawn from a wide variety of sectors, which facilitates the consistency of results with respect to the development and validation versions of the WDQ in previous studies. Participants were grouped and assigned to fourteen categories based on the twenty nine sectors of the National Classification of Economic Activities (CNAE) in Spain. It should also be noted that organizational experience $(M=111.814$ months, $S D=178.744)$ and on-the-job experience $(M=73.43$ months, $S D=102.739)$ was generally high, which ensured that responses to the WDQ were reliable. A total of $62.6 \%$ of the participants had a permanent contract, $31 \%$ had a temporary contract and $6.4 \%$ had a work or service contract. With regard to type of working day, 67\% worked a continuous working day and the remaining 33\% worked a split shift.

\section{Instruments}

In addition to questions on socio-demographic data, the online questionnaire also included the following scales:

Work characteristics: measured using the 77 items of the Spanish version of the WDQ developed by Bayona et al. (2015). The scale is composed of 21 factors, as previously explained in the section on the WDQ: work scheduling, decision-making and work methods autonomy (i.e., "The job allows me to make my own decisions about how to schedule my work"), task variety (i.e., "The job involves a great deal of task variety"), task significance (i.e., "The job has a large impact on people outside the organization"), task identity (i.e., "The job involves completing a piece of work that has an obvious beginning and end"), feedback from job (i.e., "The job itself provides me with information about my performance"), job complexity (i.e., "The tasks on the job are simple and uncomplicated"; reverse scoring), information processing (i.e., "The job requires me to analyze a lot of information"), problem solving (i.e., "The job requires me to be creative"), skill variety (i.e., "The job requires the use of a number of skills"), specialization (i.e., "The job requires a depth of knowledge and expertise"), social support (i.e., "I have the chance in my job to get to know other people"), initiated and received interdependence (i.e., "The job requires me to accomplish my job before others complete their job"), interaction outside organization (i.e., "The job involves a great deal of interaction with people outside my organization"), feedback from others (i.e., "I receive a great deal of information from my manager and co-workers about my job performance"), ergonomics (i.e., "The job involves excessive reaching"; reverse scoring), physical demands (i.e., "The job requires a great deal of muscular endurance"; reverse scoring), work conditions (i.e., "The work place is free from excessive noise"), equipment use (i.e., "The job involves the use of a variety of different equipment"; reverse scoring). The Cronbach's alpha reported by the authors ranges from .57 (ergonomics) to .95 (physical demands). Participants responded using a five-point Likert-type scale, from 1 (strongly disagree) to 5 (strongly agree).

Table 2

Number and percentage of participants by sector:

\begin{tabular}{|c|c|c|c|c|c|}
\hline \multirow{2}{*}{ Sector } & \multirow{2}{*}{$n$} & \multirow{2}{*}{$\%$} & \multicolumn{2}{|c|}{ Job seniority (months) } & \multirow{2}{*}{$\begin{array}{c}\text { Sex } \\
(\% \text { men })\end{array}$} \\
\hline & & & $M$ & $S D$ & \\
\hline Hospitality and Retail & 120 & 24 & 63.13 & 88.516 & 37.50 \\
\hline Primary sector & 89 & 17.8 & 66.83 & 92.914 & 71.91 \\
\hline Education & 58 & 11.6 & 85.74 & 117.087 & 15.52 \\
\hline Metal & 44 & 8.8 & 88.02 & 112.968 & 90.91 \\
\hline Health & 44 & 8.8 & 81.50 & 112.204 & 20.45 \\
\hline Public Administration & 32 & 6.4 & 153.41 & 151.496 & 46.88 \\
\hline Auditing and technical professionals & 27 & 5.4 & 43.93 & 49.319 & 55.56 \\
\hline Administrative/ Legal and Financial & 22 & 4.4 & 67.86 & 108.028 & 31.82 \\
\hline Research/ITC & 20 & 4 & 44.20 & 67.373 & 55.00 \\
\hline Architects/Engineers & 16 & 3.2 & 13.56 & 28.784 & 37.50 \\
\hline Tertiary Sector & 15 & 3 & 49.20 & 51.273 & 13.33 \\
\hline Transport & 8 & 1.6 & 108.75 & 120.066 & 100 \\
\hline Security/Armed forces & 3 & 0.6 & 137.00 & 188.215 & 66.67 \\
\hline Arts & 2 & 0.4 & 25.50 & 2.121 & 50.00 \\
\hline
\end{tabular}

Arts

$N=500$

Job satisfaction: measured using the 12 items of the S10S12 Job Satisfaction Questionnaire (e.g., "The support you receive from your superiors") developed by Meliá and Peiró (1989), who reported a Cronbach's coefficient of 88 .
Participants responded using a 7-point response scale, from 1 (very dissatisfied) to 7 (very satisfied).

Burnout: measured using five items from the emotional exhaustion dimension taken from the Spanish version of the 
Maslach Burnout Inventory General Survey (e.g., "I feel used up at the end of a workday") adapted into Spanish by Salanova et al. (2000), who found a Cronbach's coefficient of .85. Emotional exhaustion have been seen as the core of burnout and is the best reliable burnout dimension (e.g., Salanova et al., 2000; Schaufeli \& Dierendonck, 1993). Moreover, the content of this scale has a greater relationship with labour health issues than the other dimensions (depersonalization and reduced sense of personal accomplishment) which are more related with job performance. Participants responded using a 7-point response scale from 0 (never) to 6 (always).

Well-being: measured using the 12 items of the Spanish version of the General Health Questionnaire (e.g., "Felt constantly under strain") by Goldberg and Williams (1996), which indicated a Cronbach's Alpha of .86. Considering this instrument as unidimensional can be used for differentiating psychological morbidity (anxiety combined with depression). Participants responded using a 4-point response scale, from 0 (not at all) to 3 (much more than usual).

\section{Data analysis}

The dimensionality of the WDQ was analyzed through confirmatory factor analysis (CFA), using Mplus software (version 8.1, Muthén \& Muthén, 2012). The result of the Kolmogorov-Smirnov test with Lilliefors correction was significant $(p<.05)$, so the normality of the data could not be confirmed. We therefore used categorical weighted least squares, since these provide robust solutions (e.g., Castaño \& García-Izquierdo, 2018), and conducted bootstrapping analyses. In addition, the common method bias was verified by means of the Harman's one-factor test, described in Podsakoff et al. (2003), in which all items loaded on a single factor.

As a strategy to reduce the WDQ, two researchers took part in a two-phase inter-rater agreement process aimed at reaching an agreement as to which items should be eliminated. In the first phase, each researcher indicated the items they judged appropriate to eliminate according to the following criteria (e.g., Azañedo et al., 2017; Lloret-Segura et al., 2014): the reliability of the dimensions; the loadings of the items; and the repetitiveness of the items for each dimension. In the second phase, the researchers were able to make the appropriate modifications until total or close-tototal agreement was reached, in accordance with criteria established by Landis and Koch (1977). The reliability and factorial structure of the shorter version of the instrument were then analyzed, as well as the correlations with the original instrument (e.g. DeBode et al., 2013).

The following comparative and adjustment indexes were used to test for goodness of fit (e.g., Browne \& Cudeck, 1993): (i) comparative fit index (CFI) and Tucker-Lewis index (TLI), where values of 0.90 to 0.95 suggest an acceptable fit and values above 0.95 suggest a good fit; (ii) root mean square error of approximation (RMSEA), where values of 0.05 and below indicate a good model fit, values of
0.05 to 0.08 a moderate fit, and values of 0.10 and above a

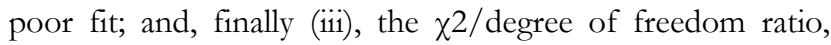
where values of between one and three suggest a good fit.

In addition, the invariance of the WDQ across gender was also analyzed. A sequential analysis was conducted for this purpose, using a configural invariance model, and applying progressive restrictions towards a metric and scalar invariance model (e.g., Elosúa, 2005; Ramis et al., 2015). Indicators of invariance were defined as incremental changes in CFI, TLI and RMSEA not exceeding $|0.01|$ (e.g., Chen, 2007; Cheung \& Rensvold, 2002).

Finally, analyses of descriptive statistics, Cronbach's reliability index, $t$-tests and Pearson's correlations were conducted using SPSS software (version 20). The calculator developed by Diedenhofen and Musch (2016) was used to compare Cronbach's reliability indices, and the calculator developed by Ellis (2009) was used to calculate the effect size. We took $d=.20$ as a small effect, $d=.50$ as a medium effect, and $d=.80$ as a large effect in $t$-tests analyses (e.g., Cohen, 1988). In addition, $G^{*}$ Power software version 3.1.9.2 by Faul et al. (2009) was used to determine $r=.144$ as the Pearson's minimum correlation coefficient with 500 participants which is sensitive to effects to $90 \%$ power $(\alpha=.05$, two-tailed), meaning that this research would not be able to reliably detect correlations smaller than that value. Missing data were then removed by means of listwise deletion.

\section{Results}

\section{Confirmatory factor analysis and reduction of the WDQ}

The results in Table 3 show that the fit for the single factor and 4-factor structure was poor, while the best fit was obtained for the structures with 18 or more factors. Being parsimonious (in order to select lower number of factors and similar RMSEA), we took as a starting point the 18 -factor structure $\left(\mathrm{RMSEA}=0.049,90 \%\right.$ CI [0.047, 0.050], $\chi^{2}=$ 5889.538, $d f=2696, \chi^{2} / d f=2.185$, TLI $=0.951$, CFI $=$ $0.954)$ in order to reduce the number of items for each dimension of the WDQ. Taking into account the criteria for reliability, factor loadings, content, and number of items per dimension described in the Data Analysis section, the first phase of the inter-rater agreement process for reducing the number of items in the WDQ resulted in a Kappa index of .54. Given that this agreement index was moderate, the second phase of the agreement process involved the pooling of the researchers' responses until total agreement was reached (Kappa index of 1) on the WDQ items to be eliminated. Specifically, in this second phase, it was agreed to eliminate 25 items, which therefore left a WDQ with 52 items. Table 4 contains a list of the 25 items eliminated from the WDQ (the original 77 items can be consulted in Bayona et al., 2015) in the second phase of constructing the shorter 52-item version of the WDQ, which we have named 
WDQ18-S. Finally, Table 3 shows the fit indices, where it can be observed that the 18-factor 52-item structure of the WDQ18-S presents adequate results with the items selected after the reduction process (RMSEA $=0.058,90 \% \mathrm{CI}$ [0.056, 0.061], $\chi^{2}=3011.491, d f=1121, \chi^{2} / d f=2.686$, TLI $=0.944, \mathrm{CFI}=0.953)$.

Table 3

Results of the CFA of the WDQ and its shortened version (WDQ 18-S).

\begin{tabular}{|c|c|c|c|c|c|c|c|}
\hline \multirow{3}{*}{ Fit indexes } & \multicolumn{7}{|c|}{ Version of the WDQ according to number of factors } \\
\hline & \multicolumn{6}{|c|}{ WDQ } & WDQ18-S* \\
\hline & 1 & 4 & 18 & 19 & 20 & 21 & 18 \\
\hline RMSEA & 0.151 & 0.099 & 0.049 & 0.048 & 0.048 & 0.048 & 0.058 \\
\hline $90 \% C I$ & {$[0.149,0.152]$} & {$[0.098,0.100]$} & {$[0.047,0.050]$} & {$[0.047,0.050]$} & {$[0.047,0.050]$} & {$[0.046,0.050]$} & {$[0.056,0.061]$} \\
\hline$\chi^{2}$ & 35143.202 & 16781.651 & 5889.538 & 5821.009 & 5772.587 & 5702.349 & 3011.491 \\
\hline$d f$ & 2849 & 2843 & 2696 & 2678 & 2659 & 2639 & 1121 \\
\hline$\chi^{2} / d f$ & 12.335 & 5.903 & 2.185 & 2.174 & 2.171 & 2.161 & 2.686 \\
\hline TLI & 0.526 & 0.795 & 0.951 & 0.951 & 0.951 & 0.952 & 0.944 \\
\hline CFI & 0.539 & 0.801 & 0.954 & 0.955 & 0.956 & 0.956 & 0.953 \\
\hline
\end{tabular}

$N=500$. Bootstrap analyses were performed to ensure robustness.

*Shortened version with 52 items.

Table 4

Eliminated items as a result of the inter-rater agreement process used to establish the WDQ18-S.

$\mathrm{N}^{\mathrm{o}}$

Items

Autonomy

2 The job allows me to decide on the order in which things are done on the job.

5 The job allows me to make a lot of decisions on my own.

7 The job allows me to make decisions about what methods I use to complete my work.

8 The job gives me considerable opportunity for independence and freedom in how I do the work.

9 The job allows me to decide on my own how to go about doing my work.

Task variety

12 The job requires the performance of a wide range of tasks.

13 The job involves performing a variety of tasks.

Task significance

17 The work performed on the job has a significant impact on people outside the organization.

Task identity

21 The job allows me to complete work I start.

Feedback from job

23 The job itself provides feedback on my performance.

Job complexity

25 The job requires that I only do one task or activity at a time. (Reverse scored)

28 The job involves performing relatively simple tasks. (Reverse scored)

Information processing

29 The job requires me to monitor a great deal of information.

31 The job requires me to keep track of more than one thing at a time.

Skill variety

37 The job requires a variety of skills.

39 The job requires me to use a number of complex or high-level skills.

Specialization

42 The tools, procedures, materials, and so forth used on this job are highly specialized in terms of purpose.

43 The job requires very specialized knowledge and skills.

Social support

45 I have the opportunity to develop close friendships in my job.

47 I have the opportunity to meet with others in my work.

Initiated and received interdependence

52 Other jobs depend directly on my job.

54 The job activities are greatly affected by the work of many different people for its completion.

Interaction outside organization

57 The job requires spending a great deal of time with people outside my organization.

58 The job involves interaction with people who are not members of my organization.

Feedback from others

63 I receive feedback on my performance from other people in my organization (such as my manager or co-workers). 
The WDQ18-S was subsequently analyzed in order to verify the extent to which it continued to measure the constructs of the original WDQ18. For this purpose, the 18 dimensions of the 52-item WDQ18-S were correlated with the corresponding 18 dimensions of the original 77-item version. In addition, an analysis was carried out to determine whether there were significant differences between the reliability indices of the dimensions of the two versions. Table 5 shows high correlations exceeding 9 , between the dimensions of the original WDQ and the WDQ18-S. It should also be noted that in 10 of the 18 dimensions of the WDQ there were statistically significant differences between the comparative reliabilities of the two versions, with a lower value obtained for the shorter version, although this lower value was less than $10 \%$ for 9 of the 10 dimensions: autonomy, task variety, task significance, task identity, feedback from job, skill variety, social support, initiated and received interdependence and feedback from others. However, although there was a more than $10 \%$ decrease with respect to the original version, in the case of the remaining specialization dimension, the reliability index was higher than .75 .

Table 5

Correlations and reliability comparison between the dimensions of the original 18-factor WDQ and the WDQ18-S.

\begin{tabular}{|c|c|c|c|c|}
\hline $\begin{array}{c}\text { Dimensions of the WDQ } \\
\text { (18 factors) }\end{array}$ & $r$ WDQ 18 factors and WDQ18-S & $\begin{array}{c}\alpha \\
\text { WDQ } 18\end{array}$ & $\begin{array}{c}\alpha \\
\text { WDQ18-S }\end{array}$ & $p$ values for $\alpha$ differences \\
\hline Autonomy & $.974^{* *}$ & .948 & .890 & .000 \\
\hline Task variety & $.965^{* *}$ & .949 & .898 & .000 \\
\hline Task significance & $.952^{* *}$ & .884 & .815 & .000 \\
\hline Task identity & $.981^{* *}$ & .854 & .790 & .003 \\
\hline Feedback from job & $.980^{* *}$ & 907 & .841 & .000 \\
\hline Job complexity & $.938^{* *}$ & .819 & .827 & .742 \\
\hline Information processing & $.931^{* *}$ & .831 & .831 & 1.000 \\
\hline Problem solving & $1.000^{* *}$ & .775 & .775 & 1.000 \\
\hline Skill variety & $.964^{* *}$ & .914 & .878 & .001 \\
\hline Specialization & $.954^{* *}$ & 891 & .779 & .000 \\
\hline Social support & $.965^{* *}$ & .855 & .788 & .001 \\
\hline Initiated and received interdependence & $.980^{* *}$ & .886 & .817 & .000 \\
\hline Interaction outside organization & $.949^{* *}$ & 917 & .902 & 222 \\
\hline Feedback from others & $.985^{* *}$ & 920 & .857 & .000 \\
\hline Ergonomics & $1.000^{* *}$ & .695 & .695 & 1.000 \\
\hline Physical demands & $1.000^{* *}$ & .961 & .961 & 1.000 \\
\hline Work conditions & $1.000^{* *}$ & .801 & .801 & 1.000 \\
\hline Equipment use & $1.000^{* *}$ & .742 & .742 & 1.000 \\
\hline
\end{tabular}

Note. $N=500$. Bootstrap analyses were performed to ensure robustness. Significant $p$ values are indicated in italics.

*Two tail significant at $p<.05$. ${ }^{*}$ Two tail significant at $p<.01$.

Measurement invariance analyses were also conducted considering gender. As shown in Table 6, the fit indices obtained for the configural model allowed us to accept the equivalence of the instrument for the two groups. Subsequently, the metric invariance model also presented a good fit, and there was no increase in the indices with respect to the less restrictive model. Finally, given that the scalar invariance model also presented good fit indices, and following the established criteria, the absolute increase in the CFI, TLI and RMSEA did not exceed 0.01 , the scalar invariance model could also be accepted.

Table 6

Gender invariance results of the WDQ18-S.

\begin{tabular}{lccc}
\hline \multirow{2}{*}{ Fit indexes } & \multicolumn{3}{c}{ Invariance } \\
\cline { 2 - 4 } & Configural & Metric & Scalar \\
\hline RMSEA & 0.055 & 0.054 & 0.053 \\
$90 \% C I$ & {$[0.052,0.058]$} & {$[0.051,0.057]$} & {$[0.050,0.056]$} \\
$\chi^{2}$ & 4221.255 & 4210.750 & 4125.031 \\
$d f$ & 2398 & 2432 & 2414 \\
$\chi^{2} / d f$ & 1.760 & 1.731 & 1.709 \\
TLI & 0.943 & 0.946 & 0.947 \\
CFI & 0.949 & 0.950 & 0.952 \\
\hline
\end{tabular}

$N=500$.

\section{Criterion-oriented validity}

Table 7 shows the descriptive statistics of the dimensions of the WDQ18-S and the criterion variables.

Table 8 shows the correlations between the dimensions of the WDQ18-S and the other variables. With regard to the significant correlations between the dimensions of the WDQ18$\mathrm{S}$ and health variables, we highlight those above $r=.144$. This is the coefficient sensitive to effects with $90 \%$ power $(\alpha=.05$, two-tailed) for our sample size, that is: (i) job satisfaction correlated significantly and positively with: autonomy, task significance, task identity, feedback from job, specialization, social support, feedback from others, ergonomics, physical demands and work conditions; (ii) emotional exhaustion correlated negatively with autonomy, task significance, feedback from job, social support, ergonomics, physical demands, and work conditions; and (iii) well-being correlated positively with autonomy, task variety, task significance, task identity, feedback from job, social support and ergonomics. We need to remind that physical demands and ergonomics are reverse scored. 
Table 7. Descriptive statistics of the WDQ18-S and criteria.

\begin{tabular}{|c|c|c|c|c|c|c|c|c|}
\hline Variables & Min. & Max. & Sum & Scale max. scoring* & $M$ & $S D$ & Skew. & Kurt. \\
\hline \multicolumn{9}{|l|}{ Task characteristics } \\
\hline Autonomy & 4 & 20 & 6,913 & 20 & 13.83 & 4.011 & -0.597 & -0.223 \\
\hline Task variety & 2 & 10 & 3,839 & 10 & 7.68 & 2.022 & -0.691 & -0.174 \\
\hline Task significance & 3 & 15 & 5,566 & 15 & 11.13 & 3.024 & -0.673 & 0.183 \\
\hline Task identity & 3 & 15 & 5,514 & 15 & 11.03 & 2.684 & -0.532 & -0.003 \\
\hline Feedback from job & 2 & 10 & 3,563 & 10 & 7.13 & 1.802 & -0.525 & 0.091 \\
\hline \multicolumn{9}{|l|}{ Knowledge characteristics } \\
\hline Job complexity & 2 & 10 & 3,435 & 10 & 6.87 & 2.135 & -0.356 & -0.647 \\
\hline Information processing & 2 & 10 & 3,604 & 10 & 7.21 & 1.999 & -0.483 & -0.329 \\
\hline Problem solving & 4 & 20 & 6,631 & 20 & 13.26 & 3.742 & -0.283 & -0.200 \\
\hline Skill variety & 2 & 10 & 3,807 & 10 & 7.61 & 1.742 & -0.557 & 0.092 \\
\hline Specialization & 2 & 10 & 3,473 & 10 & 6.95 & 1.937 & -0.464 & -0.218 \\
\hline \multicolumn{9}{|l|}{ Social characteristics } \\
\hline Social support & 6 & 20 & 7,745 & 20 & 15.49 & 3.111 & -0.488 & -0.120 \\
\hline Initiated and received interdependence & 4 & 20 & 6,729 & 20 & 13.46 & 3.902 & -0.548 & -0.122 \\
\hline Interaction outside organization & 2 & 10 & 3,597 & 10 & 7.19 & 2.372 & -0.590 & -0.574 \\
\hline Feedback from others & 2 & 10 & 3,203 & 10 & 6.41 & 2.061 & -0.269 & -0.542 \\
\hline \multicolumn{9}{|l|}{ Work context } \\
\hline Ergonomics & 3 & 15 & 4,880 & 15 & 9.76 & 2.935 & -0.172 & -0.608 \\
\hline Physical demands & 3 & 15 & 5,581 & 15 & 11.16 & 3.746 & -0.628 & -0.776 \\
\hline Work conditions & 5 & 25 & 8,264 & 25 & 16.53 & 4.928 & -0.351 & -0.465 \\
\hline Equipment use & 3 & 15 & 4,357 & 15 & 8.71 & 2.897 & 0.225 & -0.455 \\
\hline \multicolumn{9}{|l|}{ Criteria } \\
\hline Job satisfaction & 12 & 84 & 29,560 & 84 & 59.12 & 15.040 & -0.581 & -0.257 \\
\hline Emotional exhaustion & 0 & 30 & 5,915 & 35 & 11.83 & 6.740 & 0.532 & -0.239 \\
\hline Well-being & 3 & 36 & 11,542 & 48 & 23.08 & 5.892 & -0.114 & 0.030 \\
\hline
\end{tabular}

$N=500$

*Scale maximum scoring refers to the maximum score that participants can obtain on every scale. 


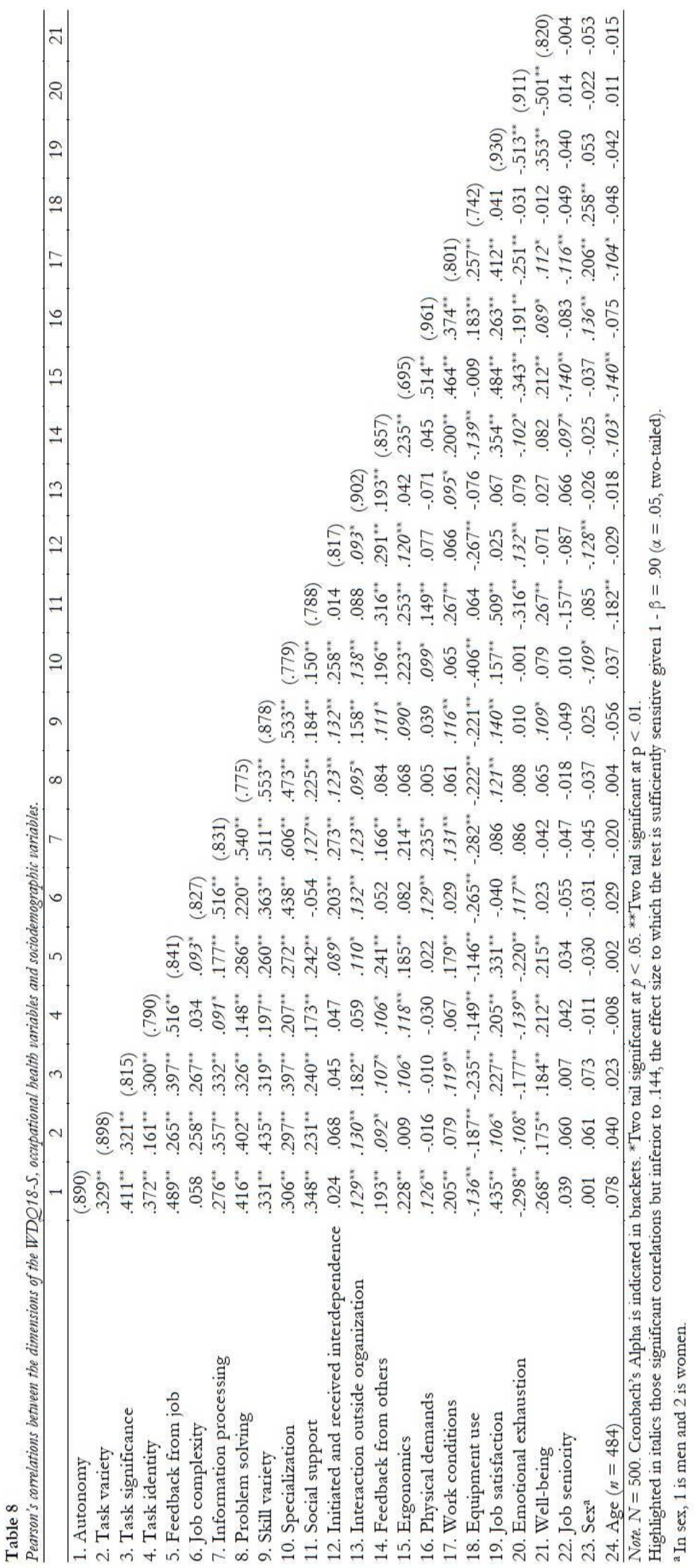


Moreover, Table 9 shows the analyses of mean differences for the dimensions of the WDQ18-S and occupational health outcomes by gender. Statistically significant differences were found showing a small effect size for the following dimensions of the WDQ18-S: specialization $(p=.014, d=0.219)$ and initiated and received interdependence $(p=.008, d=0.259)$, with higher scores for men than for women; while in physical demands $(p=$ $.004, d=-0.274)$, work conditions $(p=.002, d=-0.417)$ and equipment use $(p=.002, d=-0.538)$, higher scores were found for women than for men, reflecting a small to medium effect.

Table 9. T-test for equality of means between WDQ18-S and occupational health variables depending on gender.

\begin{tabular}{|c|c|c|c|c|c|c|c|}
\hline \multirow[t]{2}{*}{ Variables } & \multirow{2}{*}{ Bootstrap $p$ value } & \multirow[t]{2}{*}{$95 \% C I$} & \multirow[t]{2}{*}{$d$ of Cohen } & \multicolumn{2}{|c|}{$\begin{array}{c}\text { Men } \\
n=234\end{array}$} & \multicolumn{2}{|c|}{$\begin{array}{l}\text { Women } \\
n=266\end{array}$} \\
\hline & & & & $M$ & $S D$ & $M$ & $S D$ \\
\hline Autonomy & .978 & {$[-0.743,0.733]$} & $d=-0.003$ & 13.82 & 3.873 & 13.83 & 4.137 \\
\hline Task variety & .174 & {$[-0.577,0.157]$} & $d=-0.122$ & 7.55 & 1.994 & 7.79 & 2.044 \\
\hline Task significance & .122 & {$[-1.046,0.082]$} & $d=-0.146$ & 10.90 & 2.969 & 11.34 & 3.063 \\
\hline Task identity & .794 & {$[-0.371,0.520]$} & $d=0.022$ & 11.06 & 2.548 & 11.00 & 2.803 \\
\hline Feedback from job & .509 & {$[-0.184,0.431]$} & $d=0.060$ & 7.18 & 1.776 & 7.08 & 1.827 \\
\hline Job complexity & .533 & {$[-0.264,0.512]$} & $d=0.062$ & 6.94 & 2.100 & 6.81 & 2.168 \\
\hline Information processing & .329 & {$[-0.176,0.531]$} & $d=0.089$ & 7.30 & 1.991 & 7.12 & 2.007 \\
\hline Problem solving & .399 & {$[-0.397,0.937]$} & $d=0.075$ & 13.41 & 3.504 & 13.13 & 3.942 \\
\hline Skill variety & .559 & {$[-0.395,0.223]$} & $d=-0.049$ & 7.57 & 1.723 & 7.65 & 1.761 \\
\hline Specialization & .014 & {$[0.058,0.769]$} & $d=0.219$ & 7.17 & 1.822 & 6.75 & 2.015 \\
\hline Social support & .068 & {$[-1.097,0.024]$} & $d=-0.170$ & 15.21 & 3.013 & 15.74 & 3.180 \\
\hline Initiated and received interdependence & .008 & {$[0.369,1.688]$} & $d=0.259$ & 13.99 & 3.826 & 12.99 & 3.916 \\
\hline Interaction outside organization & .547 & {$[-0.360,0.545]$} & $d=0.053$ & 7.26 & 2.317 & 7.14 & 2.422 \\
\hline Feedback from others & .576 & {$[-0.215,0.492]$} & $d=0.051$ & 6.46 & 2.028 & 6.36 & 2.093 \\
\hline Ergonomics & .389 & {$[-0.275,0.738]$} & $d=0.074$ & 9.88 & 2.885 & 9.66 & 2.980 \\
\hline Physical demands & .004 & {$[-1.674,-0.416]$} & $d=-0.274$ & 10.62 & 3.822 & 11.64 & 3.618 \\
\hline Work conditions & .002 & {$[-2.827,-1.145]$} & $d=-0.417$ & 15.44 & 5.367 & 17.48 & 4.295 \\
\hline Equipment use & .002 & {$[-1.987,-0.947]$} & $d=-0.538$ & 7.92 & 2.635 & 9.41 & 2.941 \\
\hline Job satisfaction & .248 & {$[-4.120,0.912]$} & $d=-0.107$ & 58.27 & 15.802 & 59.87 & 14.325 \\
\hline Emotional exhaustion & .645 & {$[-0.827,1.417]$} & $d=0.044$ & 11.99 & 6.810 & 11.69 & 6.688 \\
\hline Well-being & .230 & {$[-0.357,1.626]$} & $d=0.107$ & 23.42 & 5.881 & 22.79 & 5.896 \\
\hline
\end{tabular}

\section{Discussion and conclusions}

This study developed a shorter version of the WDQ and subsequently analyzed the questionnaire's psychometric properties in a multi-sectoral sample of workers in Spain, with due consideration given to gender differences for the dimensions of the WDQ18-S and occupational health outcomes. The main results obtained are discussed below.

We believe that the resulting WDQ18-S constitutes an instrument that can ensure sound psychometric performance while remaining versatile in terms of its application and interpretation for the purposes of research and for occupational health and safety professionals.

With regard to the first objective, the number of items in the WDQ was shortened to the 52 found in the WDQ18-S, with a factorial structure of 18 dimensions. In addition, the invariance of the WDQ18-S across gender was also verified, which ensures equivalent measurement, as hypothesized in the second objective of this study. This shorter version of the questionnaire facilitates the application of the instrument by reducing response time, respondent fatigue and higher test-taking motivation (e.g., Liu \& Wronski, 2018; Marcus et al., 2007) without compromising its psychometric properties.
This reduction also facilitates time saving and the completion of the questionnaire, especially when applied to workers with lower qualifications and/or training. The items have been selected based on relevance, variability, and representativity (Muñiz \& Fonseca-Pedrero, 2019), as we have taken into account factor loadings, reliability analyses and the content validity of the items also to avoid overrepresentation by their repetition, finally resulting in a more easy-to-use instrument. In addition, among the advantages of the WDQ18-S it should be noted that the management time for the evaluators is reduced as well, so the instrument is easier to apply and to interpret due to the simplification of the dimensions that compose it. Ultimately, this will facilitate to conduct psychosocial assessments into organizations, often limited by the scarce availability of free, easily to apply and interpretable assessment instruments.

With respect to criterion-oriented validity evidence, H1H3 were partially fulfilled. Generally speaking, the results found for the validation of the WDQ18-S are in the same line with those obtained for job satisfaction from previous studies that we have summarized in Table 1. However, it should be outlined some larger differences as can be seen in Table 1. Following the calculated sensitivity criterion $(r>.144)$, we did not find the expected significant 
correlation with job satisfaction in the case of task variety, job complexity, information processing, problem solving, skill variety and interaction outside organization. Something similar occurs when analyzing the correlations between the dimensions of the WDQ18-S and emotional exhaustion and well-being following that restrictive criterion. The selection of this more restrictive approach to the interpretation of our data allows for rigorous conclusions, taking also into account that the sample is made up of a wide variety of sectors. Therefore, it is not surprising to say no significant correlations have been found between the health variables and some WDQ18-S dimensions such as job complexity, information processing, problem solving, skill variety, initiated and received interdependence, interaction outside the organization and equipment use, as the variety of the occupations in the sample may make it difficult for significant correlations to emerge. In this respect, the absence of a significant correlation could be related with the job content and responsibilities (i.e., differences in cognitive workload, pace of work, etc.), so further analyses should investigate if these characteristics make a difference. Furthermore, dealing with initiated and received interdependence, interaction outside organization and equipment use, our results confirm those of previous studies (e.g., Bayona et al., 2015; Morgeson \& Humphrey, 2006) regarding the non-significant relationship of these dimensions with the health outcomes, so probably these are three dimensions prone to be removed from the WDQ. Notwithstanding the above, in general, it should be noted that 11 of the 18 dimensions of the WDQ18-S were related to some extent to job satisfaction, emotional exhaustion and well-being. Moreover, we can outline autonomy, task significance, feedback from job, social support and ergonomics as the dimensions of the WDQ18-S strongly related to all the three dependent variables. In fact, previous research has already suggested that autonomy and social support were the two best predictors of job satisfaction (Humphrey et al., 2007). Consequently, our results add three more dimensions that are also relevant for the prediction of all of the criteria considered in this study, thus constituting the five most relevant dimensions of the WDQ18-S that organizations and future research should pay special attention to, for risk prevention purposes.

In a similar vein, it should also be mentioned that a significant and negative correlation of both job seniority and age, was found with social support. This seems to point to an issue of particular relevance today, namely the focus on healthy ageing in organizations (e.g., Alcover et al., 2021). From an inclusive prevention perspective, it is necessary to pay attention to occupational risks by making age-sensitive organizational adaptations. Closely related to this, occupational health variables intercorrelations are high, as expected. Moreover, one of the main contribution of this piece of research is the validation of the WDQ with psychological morbidity by means of the GHQ as it explores perceptions of distress that could be manifestations of an underlying disorder (Pedrero-Pérez et al., 2020). Along with emotional exhaustion and job satisfaction, help to screen overall psychological well-being at work.

We also analyzed possible differences in the scores of women and men in occupational health outcomes, although no statistically significant differences were found to support hypothesis H4. These results could represent a positive development, given that we found no gender differentiation in occupational health, as expected on the basis of the findings of some previous research (Batz-Barbarich et al., 2018), but the fact that satisfaction and well-being scores are generally low may be due to an equivalence in exposure to adverse job characteristics for both women and men. With regard to the third objective of this study, the gender analysis of the WDQ18-S dimension scores showed that women scored higher than men in the dimensions relating to physical demands, work conditions and equipment use. In contrast, men scored higher than women on specialization and initiated and received interdependence. These results suggest a possible consolidation of differentiated gender roles at work, as previously mentioned, with more women found in feminized jobs with less responsibility and complexity, and men working in more masculinized jobs with greater responsibility, more dependence on others and greater specialization and use of technologies (e.g., Castaño et al. 2020). In short, research on occupational health from a gender perspective becomes more necessarily than ever for greater clarification and deeper understanding of the relationship between the characteristics of work and its impact on health, thereby facilitating the development of healthy and sustainable organizations.

All in all, these results could be of particular use when it comes to considering workplace interventions and work design that contribute to the safeguarding and improvement of workers' well-being. We need to remind that despite the fact that psychological complaints are the second workrelated health problem in Europe and the wide range of studies linking working conditions and health, it is necessary to emphasize the importance of interventions in organizations, since following Sureda et al. (2019), there is sufficient empirical evidence on the benefits of reducing negative working conditions and its positive effect on the satisfaction, well-being and health of workers.

\section{Limitations and future research}

It is important to mention the limitations of the present study, as well as lines of future research. Firstly, the fact that this is a cross-sectional study makes it difficult to establish causal relationships between work characteristics and occupational health outcomes, and the results may be affected by the problem of common variance. It would therefore be interesting to carry out longitudinal studies to analyze the causal relationships between organizational factors, their consequences, and their evolution over time, in 
order to establish the interventions that most closely correspond to reality.

Secondly, the fact that the participants belong to different organizations prevents detailed data analysis that takes into account other types of organizational variables that may have affected the results obtained. In this regard, it would be particularly useful to have a sample of each relevant organizational sector in Spain that is large enough to allow a comparative analysis. This broadening of the sample by sector would also enable an exhaustive analysis of the effects of occupational segregation across gender, and the possible impact of gender stereotypes on occupational health.

Thirdly, although our sample size is not so big, we must emphasize the use of robust analysis techniques for reducing these potentials adverse effects. Thus, our results can be of interest due sector variety and gender balanced sample composition as well. Nevertheless, we highlight the need to study these job characteristics in more detail, in order to

\section{References}

Aguado, D., Andrés, J. C., García-Izquierdo, A. L., \& Rodríguez, J. (2019). LinkedIn "Big Four": Job performance validation in the ICT sector. Journal of Work and Organizational Psychology, 35(2), 53-64. https://doi.org/10.5093/jwop2019a7

Alcover, C. M., Guglielmi, D., Depolo, M., \& Mazzetti, G. (2021). "Aging-andTech Job Vulnerability": A proposed framework on the dual impact of aging and AI, robotics, and automation among older workers. Organizational $\begin{array}{lll}\text { Psychology Review, } & 11(2), & 175-201 .\end{array}$ https://doi.org/10.1177/2041386621992105

Azañedo, C. M., Fernández-Abascal, E. G., \& Barraca, J. (2017). The short form of the VIA Inventory of Strengths. Psicothema, 29(2), 254-260. https://doi.org/10.7334/psicothema2016.225

Bargsted, M., Ramírez-Vielma, R., \& Yeves, J. (2019). Professional self-efficacy and job satisfaction: The mediator role of work design. Journal of Work, and Organizational Psychology, 35, 157-163. https://doi.org/10.5093/jwop2019a18

Batz-Barbarich, C., Tay, L., Kuykendall, L., \& Cheung, H. K. (2018). A MetaAnalysis of Gender Differences in Subjective Well-Being: Estimating Effect Sizes and Associations With Gender Inequality. Psychological Science, 29(9), 1491-1503. https://doi.org/10.1177\%2F0956797618774796

Baumgartner, H., \& Steenkamp, J.-B. E. M. (2001). Response Styles in Marketing Research: A Cross-National Investigation. Journal of Marketing Research, 38(2), 143-156. https://doi.org/10.1509/jmkr.38.2.143.18840

Bayona, J. A., Caballer, A., \& Peiró, J. M. (2015). The work design questionnaire: Spanish version and validation. Revista de Psicología Del Trabajo y de Las Organizaciones, 31(3), 187-200. https://doi.org/10.1016/j.rpto.2015.06.001

Bertolino, M., Angel, V., \& Steiner, D. D. (2011). Traduction du Questionnaire sur les caractéristiques du poste de Morgeson et Humphrey (2006) [French Translation of the Work Design Questionnaire (WDQ) of Morgeson and Humphrey (2006)]. https://www.psychologie.uni-

frankfurt.de/56107021/Bertolino__Angel___Steiner_French_version_of WDQ.pdf

Borges-Andrade, J. E., Peixoto, A. L. A., Queiroga, F., \& Pérez-Nebra, A. R. (2019). Adaptation of the Work Design Questionnaire to Brazil. Revista Psicologia Organizacões e Trabalbo, 19(3), 720-731. https://doi.org/10.17652/rpot/2019.3.16837

Browne, M., \& Cudeck, R. (1993). Alternative ways of assessing model fit. In K. A. Bollen, \& J. S. Long (Eds.), Testing structural equation models (pp. 136-162). Sage.

Castaño, A. M., Fontanil, Y., \& García-Izquierdo, A. L. (2019). Why Can’t I Become a Manager?-A Systematic Review of Gender Stereotypes and Organizational Discrimination. International Journal of Environmental Research and Public Health, 16(10), 1813. https://doi.org/10.3390/ijerph16101813

Castaño, A. M., \& García-Izquierdo, A. L. (2018). Validity evidence of the Organizational Justice Scale in Spain. Psicothema, 30(3), 344-350. http://dx.doi.org/10.7334/psicothema2017.415 analyze their relationship with other important organizational outcomes such as job performance.

Data availability statement.- The data that support the findings of this study are available on request from the corresponding author, ALGI. The data are not publicly available due to their containing information that could compromise the privacy of research participants.

Disclosure statement.- No potential conflict of interest was reported by the authors.

Funding.- The authors disclosed receipt of the following financial support for the research, authorship and/or publication of this article: Ministerio de Economía y Competitividad and Fondos Sociales Europeos (reference PSI-2013-44854R), Cátedra Asturias Prevención (reference CATI-04-2018), and Consejería de Economía y Empleo del Gobierno del Principado de Asturias and Fondos Europeos de Desarrollo Regional (reference FC-GRUPINIDI/2018/000132).

Castaño, A. M., Lubiano, M. A., \& García-Izquierdo, A. L. (2020). Gendered Beliefs in STEM Undergraduates: A Comparative Analysis of Fuzzy Rating $\begin{array}{llll}\text { versus Likert Scales. Sustainability, } & \text { 12(15), } 6227 .\end{array}$ https://doi.org/10.3390/su12156227

Chen, F. F. (2007). Sensitivity of goodness of fi t indexes to lack of measurement invariance. Structural Equation Modeling: A Multidisciplinary Journal, 14(3), 464 504. http://dx.doi.org/10.1080/10705510701301834.

Cheung, G. W., \& Rensvold, R. B. (2002). Evaluating goodness-of-fit indexes for testing measurement invariance. Structural Equation Modeling, 9(2), 233-255. https://doi.org/10.1207/S15328007SEM0902_5

Cifre, E., Vera, M., \& Signani, F. (2015). Women and men at work: analyzing occupational stress and well-being from a gender perspective. Revista $\begin{array}{llll}\text { Puertorriqueña de Psicologia, 26(2), } & \text { 172-191. }\end{array}$ https://dialnet.unirioja.es/servlet/articulo? codigo $=5891769$

Cohen, J. (1988). Statistical power analysis for the bebavioural sciences. Academic Press.

Cox, T., \& Griffiths, A. J. (1996). The assessment of psychosocial hazards at work. In M. J. Schabracq, J. A. M. Winnubst, \& C. L. Cooper (Eds.), Handbook of Work and Health Psychology (pp. 127-146). Wiley and Sons.

DeBode, J. D., Armenakis, A. A., Feild, H. S., \& Walker, A. G. (2013). Assessing Ethical Organizational Culture: Refinement of a Scale. The Journal of Applied Behavioral Science, 49(4), 460-484. https://doi.org/10.1177/0021886313500987

DeSimone, J. A., \& Harms, P. D. (2018). Dirty data: The effects of screening respondents who provide low-quality data in survey research. Journal of Business and Psychology, 33(5), 559-577. https://doi.org/10.1007/s10869-0179514-9

Diedenhofen, B., \& Musch, J. (2016). cocron: A web interface and R package for the statistical comparison of Cronbach's alpha coefficients. International Journal of Internet Science, 11(1), 51-60. https://www.ijis.net/iijis11_1/ijis11_1_diedenhofen_and_musch.pdf

Eagly, A. H., \& Karau, S. J. (2002). Role congruity theory of prejudice toward female leaders. Psychological review, 109(3), 573-598. http://dx.doi.org/10.1037/0033-295X.109.3.573

Ellis, P. D. (2009). Effect size calculators. http://www.polyu.edu.hk/mm/effectsizefaqs/calculator/calculator.html

Elosúa, P. (2005). Evaluación progresiva de la invarianza factorial entre las versiones original y adaptada de una escala de autoconcepto [Progressive evaluation of factor invariance between the original and adapted versions of a self-concept scale]. Psicothema, 17(2), 356-362. http://www.psicothema.com/psicothema.asp?id=3112

Faul, F., Erdfelder, E., Buchner, A., \& Lang, A.-G. (2009). Statistical power analyses using $G^{*}$ Power 3.1: Tests for correlation and regression analyses. Behavior Research Methods, 41(4), 1149-1160. https://doi.org/10.3758/BRM.41.4.1149 
Fernández, M., Ramírez, R., Sánchez, J. C., Bargsted, M., Polo, J. D., \& Ruiz, M. A. (2017). Spanish-Language Adaptation of Morgeson and Humphrey's Work Design Questionnaire (WDQ). The Spanish Journal of Psychology, 20, e28, 1-30. https://doi.org/10.1017/sjp.2017.24

García-Izquierdo, A. L., Fernández-Méndez, C., \& Arrondo-García, R. (2018). Gender Diversity on Boards of Directors and Remuneration Committees: The Influence on Listed Companies in Spain. Frontiers in Psychology, 9. https://doi.org/10.3389/fpsyg.2018.01351

García-Izquierdo, A. L., Aguado, D., \& Ponsoda-Gil, V. (2019). New Insights on Technology and Assessment: Introduction to JWOP Special Issue. Journal of Work and Organizational Psychology, 35, 49-52. https://doi.org/10.5093/jwop2019a6

Gartzia, L., Pizarro, J., \& Baniandres, J. (2018). Emotional Androgyny: A Preventive Factor of Psychosocial Risks at Work? Frontiers in Psychology, 9. https://doi.org/10.3389/fpsyg.2018.02144

Goldberg, D., \& Williams, P. (1996). Cuestionario de Salud General GHQ (General Health Questionnaire). Guia para el usuario de las distintas versiones /General Health Questionnaire GHQ (General Health Questionnaire). User's guide for the different versions]. Masson.

Gorgievski-Duijvesteijn, M., Peeters, P., Rietzschel, E. F., \& Bipp, T. (2016). Reliability and validity of the Dutch translation of the work design questionnaire. Gedrag En Organisatie: Tijdscbrift Voor Sociale, Arbeids- En Organisatie-Psychologie, 29(3), 273-301. http://hdl.handle.net/1765/94861

Humphrey, S. E., Nahrgang, J. D., \& Morgeson, F. P. (2007). Integrating motivational, social, and contextual work design features: A meta-analytic summary and theoretical extension of the work design literature. Journal of Applied Psychology, 92(5), 1332-1356. https://doi.org/10.1037/00219010.92.5.1332

International Labor Organization. (2020). Decent work. https://www.ilo.org/global/topics/decent-work/lang--en/index.htm

Krosnick, J. A. (1999). Survey Research. Annual Review of Psychology, 50(1), $537-$ 567. https://doi.org/10.1146/annurev.psych.50.1.537

Landis, J. R., \& Koch, G. G. (1977). The measurement of observer agreement for categorical data. Biometrics, 33(1), 159-174. http://dx.doi.org/10.2307/2529310

Leka, S., \& Cox, T. (2008). PRIMA-EF - Guidance on the European Framework, for Psychosocial Risk Management: A resource for employers and worker representatives.
World
Health

http://www.who.int/occupational_health/publications/PRIMAEF\%20Guidance_9.pdf

Liu, M., \& Wronski, L. (2018). Examining Completion Rates in Web Surveys via Over 25,000 Real-World Surveys. Social Science Computer Review, 36(1), 116124. https://doi.org/10.1177/0894439317695581

Lloret-Segura, S., Ferreres-Traver, A., Hernández-Baeza, A., \& Tomás-Marco, I. (2014). El análisis factorial exploratorio de los ítems: Una guía práctica, revisada y actualizada [Exploratory Item Factor Analysis: A practical guide revised and up-dated]. Anales de Psicologia / Annals of Psychology, 30(3), 1151 1169. https://doi.org/10.6018/analesps.30.3.199361

López-Araújo, B., \& Osca, A. (2010). Influencia de algunas variables organizacionales sobre la salud y la accidentabilidad laboral [Influence of some organizational variables on occupational health and accident rate]. Annals of Psychology, https://revistas.um.es/analesps/article/view/92001

MacKenzie, S. B., \& Podsakoff, P. M. (2012). Common Method Bias in Marketing: Causes, Mechanisms, and Procedural Remedies. Journal of Retailing, 88(4), 542-555. https://doi.org/10.1016/j.jretai.2012.08.001

Marcus, B., Bosnjak, M., Lindner, S., Pilischenko, S., \& Schütz, A. (2007). Compensating for Low Topic Interest and Long Surveys: A Field Experiment on Nonresponse in Web Surveys. Social Science Computer Review, 25(3), 372-383. https://doi.org/10.1177/0894439307297606

Meliá, J. L., \& Peiró, J. M. (1989). El Cuestionario de satisfacción S10/12: Estructura Factorial, Fiabilidad y Validez [Satisfaction Questionnaire S10/12: Factor Structure, Reliability and Validity]. Revista de Psicología del Trabajo y de las Organizaciones, 4(11), 179-187. https://journals.copmadrid.org/jwop/art/00ac8ed3b4327bdd4ebbebcb2ba $10 \mathrm{a} 00$
Morgeson, F. P., \& Humphrey, S. E. (2006). The Work Design Questionnaire (WDQ): Developing and validating a comprehensive measure for assessing job design and the nature of work. Journal of Applied Psychology, 91(6), 13211339. https://doi.org/10.1037/0021-9010.91.6.1321

Muñiz, J., \& Fonseca-Pedrero, E. (2019). Diez pasos para la construcción de un test [Ten steps in test construction]. Picothema, 31(1), 7-16. https://doi.org/10.7334/psicothema2018.291

Muthén, L. K., \& Muthén, B. O. (2012). Mplus User's Guide. Seventh Edition. Muthén \& Muthén.

Osca, A., \& López-Araújo, B. (2020). Work stress, personality and occupational accidents: Should we expect differences between men and women? Safety Science, 124, 104582. https://doi.org/10.1016/j.ssci.2019.104582

Parker, S. K. (2014). Beyond Motivation: Job and Work Design for Development, Health, Ambidexterity, and More. Annual Review of Psychology, 65(1), 661-691. https://doi.org/10.1146/annurev-psych-010213-115208

Parker, S. K., Morgeson, F., Johns, G. (2017). 100 years of work design research: Looking back and looking forward. Journal of Applied Psychology, 102(3), 403420. https://doi.org/10.1037/ap10000106

Peiró, J. M., Bayona, J. A., Caballer, A., \& Di Fabio, A. (2020). Importance of work characteristics affects job performance: The mediating role of individual dispositions on the work design-performance relationships. Personality and Individual Differences, 157, 109808. https://doi.org/10.1016/j.paid.2019.109808

Pedrero-Pérez, E. J., Mora-Rodríguez, C., Rodríguez-Gómez, R., BenítezRobredo, M. T., Ordóñez-Franco, A., González-Robledo, L., \& MéndezGago, S. (2020). GHQ-12 in adolescents: contributions to the controversial factorial validity. Anales de Psicologia / Annals of Psychology, 36(2), 247-253. https://doi.org/10.6018/analesps.372721

Podsakoff, P. M., MacKenzie, S. B., Lee, J. Y., \& Podsakoff, N. P. (2003). Common method biases in behavioral research: A critical review of the literature and recommended remedies. Journal of Applied Psychology, 88(5), 879903. http://dx.doi.org/10.1037/0021-9010.88.5.879

Podsakoff, P. M., MacKenzie, S. B., \& Podsakoff, N. P. (2012). Sources of Method Bias in Social Science Research and Recommendations on How to Control It. Annual Review of Psychology, 63(1), 539-569. https://doi.org/10.1146/annurev-psych-120710-100452

Purvanova, R. K. \& Muros, J. P. (2010). Gender differences in burnout: A metaanalysis. Journal of Vocational Behavior, 77(2), 168-185. https://doi.org/10.1016/j.jvb.2010.04.006

Ramis, Y., Viladrich, C., Sousa, C., \& Jannes, C. (2015). Exploring the factorial structure of the Sport Anxiety Scale-2: Invariance across language, gender, age and type of sport. Psicothema, 27(2), 174-181. https://doi.org/10.7334/psicothema2014.263

Rivera-Torres, P., Araque-Padilla, R. A., \& Montero-Simó, M. J. (2013). Job Stress Across Gender: The Importance of Emotional and Intellectual Demands and Social Support in Women. International Journal of Environmental Research and Public Health, 10(1), 375-389. https://doi.org/10.3390/ijerph10010375

Rudman, L. A., Moss-Racusin, C. A., Phelan, J. E., \& Nauts, S. (2012). Status incongruity and backlash effects: Defending the gender hierarchy motivates prejudice against female leaders. Journal of Experimental Social Psychology, 48(1), 165-179. https://doi.org/10.1016/j.jesp.2011.10.008

Salanova, M., Llorens, S., Grau, R., Schaufeli, W. B., \& Peiró, J. M. (2000). Desde el "burnout" al "engagement": ¿una nueva perspectiva? [From "burnout" to "engagement": A new perspective?]. Revista de Psicología del Trabajo y de las Organizaciones, 16(2), 117-134. http://www.copmadrid.org/web/articulos/2000162/trabajo

Schaufeli, W. B., \& Dierendonck, D. V. (1993). The construct validity of two burnout measures. Journal of Organizational Behavior, 14(7), 631-647. https://doi.org/10.1002/job.4030140703

Stegmann, S., Dick, R. van, Ullrich, J., Charalambous, J., Menzel, B., Egold, N., \& Wu, T. T.-C. (2010). Der Work Design Questionnaire. Zeitschrift Für Arbeits- Und Organisationspsychologie A\&O, 54(1), 1-28. https://doi.org/10.1026/0932-4089/a000002Sureda, E., Mancho, J., \& Sesé, A. (2018). Psychosocial risk factors, organizational conflict and job satisfactionin Health professionals: A SEM model. Anales de Psicologia / Annals of Psychology, $\quad 35(1), \quad 106-115$. https://doi.org/10.6018/analesps.35.1.297711 